\title{
Telangiectasia in aluminium workers: a follow up
}

\author{
G THÉRIAULT, ' SUZANNE GINGRAS, ${ }^{2}$ AND SIMONE PROVENCHER'
}

From the School of Occupational Health, 'McGill University, Montreal, Québec H3A 1A3, and the Department of Social and Preventive Medicine, ${ }^{2}$ Faculty of Medicine, Laval University, Ste-Foy, Québec G1K 7P4, Canada

ABSTRACT A five step investigation was carried out to gain a better understanding of the morbidity that accompanied the development of telangiectasia on aluminium workers and to find its cause. Fifty workers with multiple telangiectasia when matched with normal controls showed the same amount of illness except that evidence of ischaemia on the ECG was found in nine cases and one control. The cases did not show an excess of abnormal biochemical tests. The basic histopathological lesion affected the surrounding tissue rather than the vessels themselves. Working in the current environment and wearing masks seems to protect young workers from developing the lesions. The Soderberg and not the prebake process was associated with the lesions; the causative agent is probably a gas that contains both hydrocarbons and fluoride components emitted from the electrolytic reactors.

In a previous study' ${ }^{1}$ we reported the presence of skin telangiectasia on numerous workers in an aluminium plant. The lesions occurred on the upper part of the body (chest, back, shoulders, forearms, neck, and face) and increased in number and size with time spent in the proximity of horizontal - Soderberg reactors. Apart from cigarette smoking, factors such as age, personal hygiene, clothing, and exposure to sunlight were not associated with the lesion. In view of the implications raised by this new problem (it had been described previously in the Soviet Union and Poland) we have pursued several lines of research; this paper summarises our most recent findings.

Aluminium is made by an electrolytic process under heat. The cathode is a steel case lined with a thick layer of carbon and the anode is made of a mixture of pitch and tar suspended in the electrolytic bath. Several additives (cryolithe, aluminium fluoride) are added to the reaction to lower the fusion temperature and to accelerate the reaction. Several airborne contaminants are emitted during the reaction, these include dusts and fumes (fluoride and iron particulates, high molecular weight hydrocarbons), gases (carbon monoxide and dioxide, sulphur dioxide, hydrogen sulphide, nitrogen oxide, hydrogen fluoride, silica fluoride, and many low molecular weight hydrocarbons) and radiation

Received 9 May 1983.

Accepted 22 August 1983 energy from heat and low frequency electromagnetic rays. ${ }^{2}$

Two processes are used; the Soderberg and the prebake. In the prebake process the anodes are precooked before their introduction into the reactor, thus decreasing sharply the amount of hydrocarbons released into the work atmosphere. ${ }^{3}$ The agent responsible for the appearance of telangiectasia in the aluminium workers is unknown but since hydrocarbons (tars) irritate the skin and have a particular affinity for organic tissues, they may be thought mainly responsible. The presence of skin telangiectasia has actually been reported in workers at a tar distillery in London. ${ }^{4}$ On the other hand, a group of Polish researchers concluded from their study of telangiectasia in aluminium workers at Skawina that fluorine plays an essential part in their pathogenesis. The purpose of the present study was to search for the causative agent and to look for any illnesses or biochemical changes accociated with these lesions.

\section{Methods}

The study was conducted in five steps as follows.

Step 1-To determine whether any specific health problems accompanied the presence of telangiectasia, the medical records of 50 workers with more than 100 telangiectasia from our previous 1978 study (cases) were compared with the records of 50 fellow workers with none (controls). Cases and controls were matched on age and seniority. The medi- 
cal records were provided by the company's health department, and details of the occupational history were made available by the personnel department. The information was collected by a physician who proceeded in a blind fashion, not knowing which records belonged to cases and which to controls.

Step 2-Physical examination, biochemical tests, and haemodynamic measurements were performed on 50 current workers, 23 bearers of several telangiectasia (cases), and 27 controls. The purpose was to determine whether the cases suffered also from any metabolic disorders. For this part of the study, since some men declined to be examined because of the necessity of a venepuncture, individual matching was not possible. The cases and the controls were therefore treated as two cohorts. The data were obtained by means of a self administered questionnaire and a physical examination by a physician. The haemodynamic tests were carried out by a nurse and the blood sample was taken by a laboratory technician. The investigation took place on the company's premises.

Step 3-Two pathologists from two separate hospital laboratories conducted optic and electronmicroscopic examination of biopsy specimens of the lesions. Two men with numerous telangiectasia agreed to participate; in one case immunofluorescence examination was also carried out.

Steps 4 and 5-Aimed at finding the causative agent of the lesions. For the past five years, workers at the plant in Shawinigan, Quebec, have been obliged to wear a mask at work which contained a fluoride captor. All workers who had worked for less than five years at the plant and, therefore, had always worn the mask were examined and the frequency of telangiectasia compared with young workers previously examined in 1978 . The purpose was to determine whether dust or fluoride particles trapped in the mask were responsible for the appearance of the telangiectasia.

Finally we compared the prevalence of workers with telangiectasia at a prebake process smelter with that observed in our previous study at the Soderberg process smelter. A difference between the two might indicate that the causative agent resides in the emissions from the Soderberg process. The prebake process plant was in Lynemouth, UK, a plant with about 750 workers, that started its operations in the early 1970s. The skin examination was carried out by one of the physicians who took part in the previous study.

\section{Results}

\section{STUDY OF EMPLOYEES' MEDICAL RECORDS}

The cases, and controls were compared on the basis of three variables: social habits, history of illnesses, and results of periodic medical examinations.

The social habits studied were alcohol consumption and smoking (table 1) and no significant difference was found between cases and controls, although in absolute figures there were fewer nonsmokers (16 v 22) and more heavy smokers (17v 13) among cases. Similarly, no significant difference was found for previous illnesses reported although, in absolute figures, the following conditions were diagnosed with greater frequency among cases; ulcer syndromes $(13 v 7)$, haemorrhoids (13v9), and obstructive lung diseases $(20 v 13)$.

The periodic medical examination showed that more cases than controls showed signs of ischaemia on their ECG (9v1, $\left.\chi^{2}=4.0, p=0.05\right)$. The proportion of ischaemic cases among cases who smoked was $11.8 \%(4 / 34)$ and among control smokers $3.6 \%(1 / 28)$. The group of workers with ischaemia included those whose ECG readings

Table 1 Results from employee's medical records (50 cases, 50 controls)

\begin{tabular}{|c|c|c|c|c|}
\hline & Cases & Controls & $\begin{array}{l}\chi^{2} M c N e m a r \\
\text { with correction }\end{array}$ & $p$ \\
\hline \multicolumn{5}{|l|}{ Social habits } \\
\hline Regular alcohol consumption & 15 & 12 & $0 \cdot 38$ & $0 \cdot 54$ \\
\hline Non-smoker & 16 & 22 & $1 \cdot 14$ & 0.29 \\
\hline Heavy smoker ( $\geqslant 20 \mathrm{cig} /$ day $)$ & 17 & 13 & 0.76 & 0.38 \\
\hline \multicolumn{5}{|l|}{ Past illnesses: } \\
\hline Ulcer syndromes & 13 & 7 & 1.79 & $0 \cdot 18$ \\
\hline Varicose veins & 6 & 5 & 0.00 & 0.76 \\
\hline Inguinal hernias & 9 & 9 & 0.06 & 0.80 \\
\hline Haemorrhoids & 13 & 9 & 0.64 & 0.42 \\
\hline \multicolumn{5}{|l|}{ Periodic examination: } \\
\hline High blood pressure $(\geqslant 160 / 95)$ & 5 & 9 & $0 \cdot 64$ & 0.42 \\
\hline Hearing loss $(\geqslant 15 \mathrm{db})$ & 28 & 27 & 0.00 & 1.00 \\
\hline FVC $(<80 \%$ predicted $)$ & 13 & 11 & 0.06 & 0.81 \\
\hline FEV,$(<80 \%$ predicted $)$ & 17 & 9 & 1.79 & 0.18 \\
\hline Haemoglobin $(>17 \mathrm{gm} / 100 \mathrm{ml})$ & 6 & 1 & $2 \cdot 29$ & 0.13 \\
\hline Ischaemia on ECG & 9 & 1 & 4.00 & 0.05 \\
\hline
\end{tabular}


made during the periodic medical examination were reported positive by the attending cardiologist and workers who were admitted to hospital for and died of myocardial infarction between 1978 and 1981 . There was no significant difference for the other measures such as blood pressure, hearing loss, pulmonary function, and haemoglobin concentration, although in absolute numbers more cases showed $\mathrm{FEV}_{1}$ below $80 \%(17 v 9)$ and a haemoglobin value higher than $17 \mathrm{mg} / 100 \mathrm{ml}(6 v 1)$ than did the controls.

In this part of the study cases and controls were matched by age and work seniority. The increased rates of cardiac ischaemia and the changes in pulmonary function and haemoglobin values among the cases could thus have resulted from different occupational exposure within the industry.

\section{Clinical investigation}

The cases and controls did not differ with respect to age, seniority, cigarette smoking, or tea, coffee, or alcohol consumption.

Table 2 shows the results of the physical examination; there are no significant differences. None of the physicians observed fundal telangiectasia; the ophthalmological abnormalities mentioned were described as increased light reflection, abnormal arteriovenous crossovers, or constricted arteries. They have little importance outside the clinical context and no bearing on telangiectasia.

Table 3 shows the results of the biochemical tests. Since cirrhosis of the liver is sometimes accompanied by telangiectasia several liver function tests were carried out but there were no more abnormalities among the cases than among the controls.

Telangiectasia occasionally occurs in pregnant women and in those using oestrogen hormones. A check for any disturbance in the androgen/oestrogen ratio in workers with telangiectasia was therefore indicated. The mechanism of this disturbance could be either through the direct action of heat on the gonads or by liver toxicity. Hormone levels were not altered in workers with telangiectasia, however, nor

Table 2 Results of the physical examination (23 cases, 27 controls)

\begin{tabular}{lclll}
\hline Physical examinations & Cases & Controls & $\chi^{2}{ }_{1}$ & $p$ \\
\hline Changes in libido & 10 & 7 & 1.74 & 0.19 \\
Other skin diseases & 3 & 3 & 0.04 & $0 \cdot 83$ \\
Abnormal findings in fundus & 10 & $5^{*}$ & 3.48 & 0.06 \\
Abnormalities in 'abdomen & 6 & 2 & 3.22 & 0.07 \\
Breast development & 0 & $0^{*}$ & - & - \\
Regular intake of medication & 7 & 5 & 0.97 & 0.33 \\
Arterial hypertension & 2 & 5 & 1.00 & 0.32 \\
\hline
\end{tabular}

*One control unknown.
Table 3 Results of the biochemical tests (23 cases, 27 controls)

\begin{tabular}{|c|c|c|c|c|}
\hline \multirow[t]{2}{*}{ Tests } & \multicolumn{2}{|c|}{ Abnormal Tests } & \multirow[t]{2}{*}{$x_{1}^{2}$} & \multirow[t]{2}{*}{$p$} \\
\hline & Cases & Controls & & \\
\hline AST (GOT) transaminase & 0 & 0 & - & - \\
\hline AlT (GPT) transaminase & 1 & 0 & 0.01 & 0.94 \\
\hline GT gamma globulin & 1 & 1 & 0.00 & $1 \cdot 00$ \\
\hline Alkaline phosphatase & 0 & 0 & - & - \\
\hline IgA immunoglobulin & 0 & 0 & - & - \\
\hline Direct bilirubin & 0 & 0 & - & - \\
\hline Indirect bilirubin & 0 & 0 & - & - \\
\hline Total bilirubin & 0 & 1 & $0 \cdot 00$ & $1 \cdot 00$ \\
\hline Total testosterone & 5 & 5 & 0.08 & 0.78 \\
\hline Free testosterone & 1 & 3 & 0.70 & $0 \cdot 40$ \\
\hline $17 \beta$ oestradiol & 1 & 0 & 0.01 & 0.94 \\
\hline \multicolumn{5}{|l|}{ Intraleukocyte alkaline } \\
\hline phosphatase & 0 & 0 & - & - \\
\hline Glycohaemoglobin & $1^{*}$ & 0 & 0.01 & 0.94 \\
\hline Pyridoxine $\left(\mathrm{B}_{\mathrm{o}}\right)$ & 1 & 0 & 0.07 & 0.94 \\
\hline Hyaluronidase & 2 & 2 & 0.00 & $1 \cdot 00$ \\
\hline Sedimentation rate & 1 & 1 & $0 \cdot 00$ & $1 \cdot 00$ \\
\hline Antinuclear antibodies & 1 & 0 & $0 \cdot 01$ & 0.94 \\
\hline Protein immunoelectrophoresis & $s 1^{*}$ & 2 & $0 \cdot 13$ & $0 \cdot 72$ \\
\hline
\end{tabular}

*One case unknown.

was breast development found on physical examination and libido was not reported to be reduced.

Telangiectasia sometimes accompany autoimmune diseases such as rheumathoid arthritis or systemic lupus erythematosus, but antinuclear antibody measurements, protein electrophoresis, and $\operatorname{IgA}$ measurements were not more frequently abnormal among the cases than the controls. Other variables such as pyridoxine (vitamin $\mathrm{B}_{6}$ ), glycohaemoglobin, hyaluronidase, and intraleukocytic alkaline phosphatase, believed to contribute to the development of telangiectasia also showed no difference between cases and controls. The same was true for sedimentation rate, blood cell counts, bleeding time, blood pressure, and pulse rate.

\section{MICROSCOPY OF THE LESIONS}

The major findings on the optical microscopic examination were the following : dilatation of the capillaries, swelling of the endothelium, the presence of a ring of mononuclear cells around the vessels, slight tumescence or fibrosis of the superficial dermis, and fragmentation of the elastic fibres in the dermis. Under electron microscope, no specific ultrastructural changes were observed, although the endothelial cells were prominent and there was evidence of elastoid degeneration of the collagenous tissue around the vessels. The telangiectasia affected the arteriolar, capillary, and postcapillary venular segments of the terminal vessels. No fibrogen, complement, or immunoglobulin deposits were detected by immunofluorescent studies of the skin biopsy specimen. 
Table 4 Prevalence of telangiectasia among recent workers

\begin{tabular}{lcr}
\hline $\begin{array}{l}\text { No of } \\
\text { telangiectasia }\end{array}$ & $\begin{array}{l}\text { No of } \\
\text { workers }\end{array}$ & $\%$ \\
\hline 0 & 46 & $40 \cdot 0$ \\
$1-9$ & 53 & $46 \cdot 1$ \\
$10-19$ & 9 & $7 \cdot 8$ \\
$20-49$ & 5 & $4 \cdot 4$ \\
$\geqslant 50$ & 2 & $1 \cdot 7$ \\
Total & 115 & $100 \cdot 0$ \\
\hline
\end{tabular}

RECENTLY EMPLOYED WORKERS' EXAMINATION All recently employed workers (115) agreed to undergo the medical examination. They were young (75\% were under 30 ), and their personal habits were similar to those of the workers examined previously:72.2\% were regular smokers and $24.3 \%$ non-smokers; $12 \cdot 2 \%$ consumed alcohol four to six times a week or more whereas the majority $(75.0 \%)$ were occasional drinkers and $12.2 \%$ never drank alcohol. Only 16 individuals $(14.0 \%)$ had 10 telangiectasia or more; three men had large lesions (table 4). The comparison between the 1978 and 1981 recently employed workers was made according to the number of years worked either at the plant, in reactor rooms, or in occupations identified in our previous study as being most responsible for the lesions (occupations in which the workers had access to open reactors). As seen from table 5, the most recently hired workers showed fewer telangiectasia than the men hired earlier, given an equal number of years of exposure. Two factors seem to have contributed to this difference, an improvement in the quality of the air in the potrooms, and the mandatory wearing of protective masks by workers in contact with the reactors. The protection offered by these measures does not seem to be fully efficient, however. Workers in at risk occupations for more than one year showed a higher prevalence of telangiectasia than those who had worked for one year or less. Several factors probably contribute to this. For example, workers often remove their masks while working and the masks are not worn outside at risk
Table 6 Prevalence of telangiectasia in Soderberg and prebake processes

\begin{tabular}{|c|c|c|c|c|}
\hline & Soderberg & Prebake & $x_{1}^{2}$ & $p$ \\
\hline & $\%(\mathrm{No})$ & $\%(N o)$ & & \\
\hline \multirow{3}{*}{$\begin{array}{l}\text { Worked in the plant } \\
\text { ( } 1 \text { to } 10 \text { years) } \\
\text { Worked in reactor room } \\
\text { ( } 1 \text { to } 10 \text { years) } \\
\text { Worked in at risk } \\
\text { occupations ( } 1 \text { to } 10 \text { years }\end{array}$} & $35 \cdot 0(123)$ & $7 \cdot 8(311)$ & $50 \cdot 11$ & $1 \cdot 0^{-9}$ \\
\hline & $41 \cdot 0(272)$ & $8 \cdot 1(148)$ & 49.49 & $1 \cdot 0^{-9}$ \\
\hline & $45.0(235)$ & $17 \cdot 5$ & 15.92 & $6 \cdot 6^{-5}$ \\
\hline
\end{tabular}

areas although the general atmosphere is contaminated.

\section{COMPARISON OF SODERBERG AND PREBAKE PROCESSES}

At the time of the survey, the prebake plant had a workforce of 576 men at various locations in the plant. The selection of men for examination was based on work areas and time schedules, and the number examined was 311 (54\% of overall workforce, $64 \%$ of production employees). The refusal rate was less than $3 \%$. As with the recently employed workers, the comparison between prebake and Soderberg employees was made according to the same number of years worked in a similar environment. Since the prebake process had been in operation for 10 years, no comparison could be made beyond that period.

For equal time worked, a much smaller proportion of workers in the prebake process had telangiectasia compared with workers in the Soderberg process (table 6). This tends to support the hypothesis that the development of telangiectasia may be due to differences in the emissions from the two processes, the most important being the much lower emission of hydrocarbon in the prebake process.

\section{Discussion}

CAUSE OF TELANGIECTASIA

The results of this study indicate that fluorides con-

Table 5 Prevalence of telangiectasia in two groups of workers examined in 1978 and 1981

\begin{tabular}{|c|c|c|c|c|}
\hline & \multicolumn{2}{|l|}{$\geqq 10 \mathrm{Telg}$} & \multicolumn{2}{|c|}{ Telg $>5 \mathrm{~mm}$} \\
\hline & $\begin{array}{l}1978 \\
\%(N o)\end{array}$ & $\begin{array}{l}1981 \\
\%(N o)\end{array}$ & $\begin{array}{l}1978 \\
\%(\mathrm{No})\end{array}$ & $\begin{array}{l}1981 \\
\%(N o)\end{array}$ \\
\hline Worked at the plant for 3 to 4 years & $16 \cdot 7(43)$ & $12 \cdot 8(47)$ & $9 \cdot 5(43)$ & $2 \cdot 1(47)$ \\
\hline $\begin{array}{l}<1 \text { year } \\
1-4 \text { years } \\
\text { Worked in at risk occupations for: }\end{array}$ & $\begin{array}{l}29 \cdot 7(128) \\
33 \cdot 5(179)\end{array}$ & $\begin{array}{l}10 \cdot 1(69)^{* *} \\
19 \cdot 6(46)\end{array}$ & $\begin{array}{l}9 \cdot 4(128) \\
8 \cdot 9(179)\end{array}$ & $\begin{array}{l}4 \cdot 3(69) \\
2 \cdot 2(46)\end{array}$ \\
\hline $\begin{array}{l}<1 \text { year } \\
1-4 \text { years }\end{array}$ & $\begin{array}{l}32 \cdot 0(244) \\
38 \cdot 7(181)\end{array}$ & $\begin{array}{l}11.4(79)^{* *} \\
19.4(36)^{*}\end{array}$ & $\begin{array}{l}10 \cdot 6(244) \\
12 \cdot 1(181)\end{array}$ & $\begin{array}{l}3 \cdot 8(79) \\
2 \cdot 8(36)\end{array}$ \\
\hline
\end{tabular}

${ }^{*} \mathrm{p}<0.05 ;{ }^{* *} \mathrm{p}<0.01$. 
tribute to the development of telangiectasia since the occupations where the lesions are more prevalent involve significant exposure to fluorides. It is also noted that the telangiectasia appear on areas of the body where workers sweat heavily and fluoride is known to be excreted partly in the sweat. ${ }^{6}$ Fluoridated cortisone may produce telangiectasia in exposed patients. ${ }^{7-11}$ With the elimination of fluoride, cortisone alone no longer produced the lesions, and a tendency to healing was observed. These observations support the view that fluoride may be a contributing factor in the production of telangiectasia.

On the other hand, there are indications that fluoride is not the only causative agent. Nowhere do published reports on fluorine toxicity mention that fluorides cause telangiectasia, and workers in a fluorine plant in Arvida, Quebec, have not developed telangiectasia. Workers in the prebake process, with the same level of exposure to fluorides as the Soderberg workers, have many fewer telangiectasia and hence it may be that telangiectasia are caused by the association of fluorides with another substance, possibly a hydrocarbon.

\section{HISTOPATHOLOGICAL LESION}

The microscopical appearance of telangiectasia suggests that the basic lesion lies more in the tissue around the vessels than within the vessel walls. This view is supported by the appearance in the dermis of fragmented elastic fibres and elastoid degeneration of the collagen. The hypertrophied endothelial cells could be a compensatory mechanism that follows the enlargement of the vessels.

The appearances are similar to those observed in people who develop telangiectasia after topical application of fluoridated cortisone. It was observed that the basic histopathological lesion was a degeneration of collagen, of elastic fibres, and of the basic mucopolysaccharide substance of the dermis. ${ }^{710}$ This lesion of the interstitial substance of the dermis appears to cause the vascular dilatation observed at the skin surface. If this is so the basic physiopathology is either a stimulation of collagenase that causes an increased degeneration of collagen, or fibroblast impairment that gradually curtails the production of collagen, elastic fibres and dermal interstitial tissue.

From these observations, the hypothesis may be put forward that telangiectasia in aluminium workers result from damage to the fibroblasts accompanied by structural abnormalities of the dermis, together creating lacunae in the supporting structure of the vessels and consequently a widening of the blood vessels which makes them more visible at the skin surface. This theory is strengthened by the inclusion in the phenomenon of all three sections of the arteriovenous junction-the arterial, the capillary, and the venous. Our opinion coincides with that of Polish workers ${ }^{5}$ who supposed that the main pathogenic factor was the disorganisation of collagen and of elasticity, leading to vascular dilatation.

\section{ASSOCIATED ILLNESSES}

The observation of ischaemic heart disease in men with numerous telangiectasia deserves special attention. The association of telangiectasia with heart disease is possibly due to chance. No other disease was reported more frequently among the cases than the controls and the biochemical, endocrine, and haematological investigations did not show great frequency of abnormalities. No telangiectasia related illnesses were reported by the cases. On the other hand, there is some suggestion that telangiectasia may be associated with organic and structural changes affecting the entire cardiovascular system, the presence of ischaemia on ECG being one serious manifestation. Russian workers, reporting on disturbances of the blood vessels in the skin and on disorders of the cardiovascular system among reactor workers in an aluminium smelter stated that, "Pathological changes affecting the skin vessels are related to changes in the capillary structure of the conjunctiva of the eyes and to organic and structural changes throughout the cardiovascular system" 12 (translation).

The observation of a high prevalance of ischaemic heart disease in men with telangiectasia should thus not be ignored. More research is required to investigate this association and to assess the extent of any damage to the vascular system as a whole.

We are indebted to La Société d'Electrolyse et de Chimie Alcan, its employees, and their union representatives for help and to Dr John Kelly for support and guidance.

Supported under a contract from the Société d'Electrolyse et de Chimie Alcan Ltée, Montréal.

Requests for reprints to Dr Thériault.

\section{References}

' Theriault G, Cordier S, Harvey R. Skin telangiectases in workers at an aluminium plant. $N$ Engl $J$ Med 1980;303:1278-81.

${ }^{2}$ Ravier EF. Technology of aluminium reduction. In: Hughe JP, ed. Health protection in primary aluminium production. London: International Primary Aluminium Institute, 1977:17-21.

${ }^{3}$ Bjorseth A, Bjorseth O, Fjeldstad PE. Polycyclic aromatic hydrocarbons in the work atmosphere. I. Determination in an aluminium reduction plant. Scand J Work Environ Health 1978;4:212-23.

- Fisher REW. Occupational skin cancer in a group of tar workers. AMA Arch Ind Hyg Occup Med 1953;7:12-8.

s Lejman K, Szwarc K, Szydlowski F. Skin lesions in workers of 
the aluminium plant in Skawina. Suplement do przegladu dermatologicznego 1976;6:117-20. (In Polish.)

- Dinman BD, Bovard WS, Bonney TB, Cohen JM, Colwell MO.

Absorption excretion of fluoride immediately after exposure pt 1. JOM 1976;18:7-13.

7 Sneldon I. A trial of hydrocortisone butyrate in the treatment of rosacea and perioral dermatitis. Br J Dermatol 1973;89:5058.

" Sneldon I. Adverse affect of topical fluorinated corticosteroids in Rosacea. Br Med J 1969;i:671-3.

${ }^{4}$ Brown SI, Weller CA, Vidrich AM. Effect of corticosteroids on corneal collagenase of rabbits. Ann J Ophthalmol 1970; 70:744-7.
"Stevanovic DV. Corticosteroid induced atrophy of the skin with telangiectasia. A clinical and experimental study. $\mathrm{Br} \mathrm{J} \mathrm{Der-}$ matol 1972;84:548-56.

"Snyder DS, Greenberg RA. Evaluation of atrophy production and vasoconstrictor potency in humans following intradermally injected corticosteroids. J Invest Dermatol 1974; 63:461-3.

12 Bazyka AP, Logunov VP, Selivonenko VG, Kozlenko VV. Relationship between occupational vascular affections of the skin and occupational disorders of the cardiovascular system in workers of the electrolysis of an aluminium plant. Vlatnik Dermatol Venerol 1977;7:73-7. (In Russian.) 